\title{
Manfaat dan Dampak Digitalisasi Logistik di Era Industri 4.0
}

\author{
Erwin Raza ${ }^{1}$, La Ode Sabaruddin ${ }^{2}$, Aziza Leila Komala ${ }^{3}$ \\ 1,2,3Fakultas Ilmu Sosial dan Manajemen, Institut Ilmu Sosial dan Manajemen STIAMI \\ Laoderudi79@gmail.com*
}

\section{ARTICLE INFO}

\section{Article History}

Received: 1 April 2020

Reviewed : 15 April 2020

Published : 30 April 2020

Available Online: 30 April

2020

Keywords:

Digitalization, Logistics,

Industry 4.0

\section{ABSTRACT}

All the time, innovative and new technologies continue to be developed. This forces anyone involved in the logistics industry to adapt so as not to be left behind and experience adverse effects. With the 4.0 industrial revolution, now many companies are starting to implement digitalization in their logistics activities. There are five main technologies that must be considered in the 4.0 Industrial Revolution, namely Artificial Intelligence (AI), Internet of Things (IoT), Wearable Technology (WT), Advanced Robotic (AR) and 3D Printing (3DP). This research was conducted to explore the benefits and impacts of digitizing the logistics process in the Industrial 4.0 era by examining it from various sources. The results showed that the use of technology for digitizing logistics provided many benefits both for individuals and for corporate organizations. The stakeholders are expected to be able to work together adequately to ensure the technology present in the Industrial 4.0 era provides the benefits that are expected.

\section{A. PENDAhULUAN}

\section{Latar Belakang}

Transformasi ke arah digitalisasi adalah proses yang sedang berlangsung di industri logistik. Sepanjang waktu, teknologi inovatif dan baru terus dikembangkan salah satunya untuk merampingkan penyampaian produk ke pelanggan secepat mungkin. Operasi logistik saat ini dan sistem informasi yang digunakan tidak dapat menghadapi tantangan yang muncul. Globalisasi, e-commerce, ancaman dunia maya, struktur organisasi yang rumit, startup yang mengganggu lanskap bisnis dan permintaan pelanggan yang semakin tinggi mendorong perusahaan untuk mengadopsi teknologi yang muncul yang memungkinkan mereka untuk meningkatkan digitalisasi dan otomatisasi. Revolusi industri keempat memungkinkan perusahaan untuk melanjutkan digitalisasi operasi mereka, karena membangun struktur organisasi yang fleksibel merupakan tantangan yang perlu ditangani dan mengadopsi model perusahaan digital adalah langkah penting sebelum menerapkan teknologi zaman baru, karena perusahaan harus menambahkan elemen fleksibilitas dan kemampuan beradaptasi untuk menghadapi tantangan yang dihadapi (Karampourniotis, 2019).

Dengan adanya revolusi industri 4.0, saat ini banyak perusahaann dari berbagai pejuru dunia mulai menerapkan digitalisasi dalam aktifitas logistik mereka. Menurut Kayikci (2018), konsep digitalisasi logistik adalah memungkinkan transparansi sepanjang waktu dari pemasok ke pelanggan atau dengan kata lain harus adanya transparansi disepanjang rantai pasokan. Selain itu, logistik harus mendapatkan visi yang lebih besar untuk memenuhi persyaratan industri 4.0 secara berkelanjutan dalam hal menggunakan teknologi yang tepat dan meningkatkan integrasi vertikal dan horizontal di antara mitra rantai pasokan.

Cahn (2019), menyatakan bahwa untuk mendapatkan stabilitas dalam ekonomi yang terus berubah, bisnis perlu menjalani transformasi digital. Banyak bisnis sudah dalam perjalanan transformasi digital; jika perusahaan belum mulai berubah, mereka harus segera melakukannya, atau ketinggalan.

Senada dengan Direktur Utama BGR Logistics, M Kuncoro Wibowo. Dikutip dari koranjakarta.com (2016) mengatakan bahwa dalam menghadapi era Industri 4.0, perusahaan logistik sudah seharusnya melakukan transformasi digital. Perusahaan dapat memanfaatkan sistem berbasis Industri 4.0 untuk dalam mendapatkan informasi akurat pergerakan barang. 
Namun pada kenyataannya membangun digitalisasi logistik bukanlah sesuatu yang mudah. Butuh kesadaran dan kemauan dari berbagai pihak yang ada dalam rantai pasokaan untuk saling bekerja bersama dalam mewujudkannya.

Di Indonesia, dikutip dari supplychainindonesia.com, Asisten Deputi Bidang Logistik Kementerian Koordinator Bidang Perekonomian, Erwin Raza (2019), menyatakan bahwa lebih rumit membangun digitalisasi untuk bisnis proses logistik domestik. "Digitalisasi domestik itu lebih rumit, mulai dari inland atau transportasi darat, permasalahannya sangat rumit. Terkait dengan dokumen saja kita tidak ada standardisasinya dan bagaimana digitalisasinya. Belum lagi, [menyangkut] tracking atau pelacakannya. Sekarang ini lebih luas lagi, karena ada yang proses bisnisnya konvensional ada yang elektronik. Apalagi bicara digitalisasi, mengubah pola pikir semua. Mau tidak mau saling membangun kepercayaan, karena kepercayaan itu penting,"

Hal tersebut dipertegas oleh Konsultan Senior Supply Chain Indonesia (SCI), Zaroni Samadi, menilai dalam rangka membangun digitalisasi logistik dibutuhkan prakondisi berupa persiapan standardisasi proses logistik dan edukasi perubahan pola pikir. Dia menjelaskan sistem e-logistics atau digitalisasi logistik sangat dibutuhkan guna meningkatkan kinerja terutama bagi pengguna jasa logistik. "E-logistics diharapkan dapat mempercepat proses informasi pergerakan material atau produk, aliran informasi, cash flow, dan aliran informasi dokumen logistik," ungkapnya.

Ketum DPP Asosiasi Logistik dan Forwarder Indonesia (ALFI) Yukki Nugharawan Hanafi mengatakan digitalisasi logistik selalu diawali dengan transformasi digital yaitu adanya perubahan business process yang memajukan nilai faster, better dan cheaper. Optimalisasi ketiga nilai digitalisasi memerlukan keterlibatan banyak pihak atau pemangku kepentingan. Keterlibatan para pemangku kepentingan tersebut tidak terbatas pada keterikatan terhadap suatu platform tertentu saja, melainkan diperlukan adanya integrasi dalam suatu ecosystem yang memberikan nilai tambah kepada seluruh pemangku kepentingan (Chon, 2019).

\section{Tujuan Penelitian}

Adapun tujuan dari penelitian ini adalah sebagai berikut:

a. Menyoroti manfaat digitalisasi proses logistik di era industri 4.0.

b. Mengetahui dampak keberlanjutan digitalisasi dalam logistik di era industri 4.0.

\section{Manfaat Penelitian}

Manfaat yang diharapkan dari penelitian ini adalah :

a. Dapat dijadikan sebagai masukan dan pertimbangan untuk menerapkan digitalisasi logistik bagi para pemangku kepentingan industri.

b. Adanya pemahaman mengenai manfaat dan dampak digitalisasi logistik di era Industri 4.0.

c. Sebagai referensi serta masukan untuk penelitian lanjutan dengan tema penelitian yang sama.

\section{Tinjauan Pustaka}

\section{Digitalisasi Logistik}

\section{Digitalisasi}

Era Digitalisasi lahir dengan serangkaian fitur dan manfaat yang dihadirkannya. Berbagai kemudahan bisa didapatkan dengan menerapkan digitalisasi baik itu dalam keseharian individu maupun dalam operasional sebuah organisasi atau perusahaan.

Menurut Sukmana (2005), digitalisasi adalah proses alih media dari bentuk tercetak, audio, maupun video menjadi bentuk digital. Digitalisasi dilakukan untuk membuat arsip dokumen bentuk digital, untuk fungsi fotokopi, dan untuk membuat koleksi perpustakaan digital. Digitalisasi memerlukan peralatan seperti komputer, scanner, operator media sumber dan software pendukung.

Menurut Lasa (2005), digitalisasi adalah proses pengelolaan dokumen tercetak/printed document menjadi dokumen elektronik. Sedangkan menurut wikipedia (2020) digitalisasi adalah proses mengubah informasi menjadi format digital (misalnya komputer-dapat dibaca), dimana informasi disusun menjadi bit.

Menurut Brennen \& Kreiss (2016), digitalisasi yaitu meningkatnya ketersediaan data digital yang dimungkinkan oleh kemajuan dalam menciptakan, mentransfer, menyimpan, dan menganalisis data digital, dan memiliki potensi untuk menyusun, membentuk, dan mempengaruhi dunia kontemporer. 


\section{Logistik}

Walters (2003) mendefinisikan logistik sebagai fungsi yang melibatkan perpindahan, mengatur perpindahan barang dan penyimpanan material dalam perjalanannya dari pengirim awal, melalui rantai pasok dan sampai ke pelanggan akhir. Sedangkan menurut Siagian (2005), logistik didefinisikan sebagai bagian dari proses rantai suplai (supply chain) yang berfungsi merencanakan, melaksanakan, mengontrol secara efektif, efisien proses pengadaan, pengelolaan, penyimpanan barang, pelayanan dan informasi mulai dari titik awal (point of origin) hingga titik konsumsi (point of consumption) dengan tujuan memenuhi kebutuhan konsumen.

Council of Logistic Management dalam Ballou (1992) mendefinisikan logistik sebagai proses perencanaan, implementasi, dan pengendalian efisiensi, aliran biaya yang efektif dan penyimpanan bahan mentah, bahan setengah jadi, barang jadi dan informasi-informasi yang berhubungan dari asal titik konsumsi dengan tujuan memenuhi kebutuhan.

Dari definisi yang telah dipaparkan tersebut dapat ditarik kesimpulan bahwa logistik adalah aliran barang atau jasa mulai dari sumber sampai tujuan yang meliputi proses perencanaan, pelaksanaan, dan pengendalian aliran yang efisien dan efektif dari barang atau jasa dan informasi terkait mulai dari titik asal sampai titik penggunaan untuk memenuhi keperluan pelanggan.

\section{Digitalisasi Logistik}

Definisi mengenai Digitalisasi Logistik dapat ditarik berdasarkan definisi digitalisasi dan logistik yaitu bahwa digitalisasi logistik merupakan rangkaian kegiatan logistik yang meliputi proses perencanaan, pelaksanaan, dan pengendalian aliran yang efisien dan efektif dari barang atau jasa dan informasi terkait mulai dari titik asal sampai titik penggunaan untuk memenuhi keperluan pelangganyang ditransformasikan ke dalam format digital.

\section{Revolusi Industri 4.0}

Istilah Industri 4.0 lahir dari ide revolusi industri ke-empat. Davies (2015) dalam Prasetyo dan Sutopo (2017) menyampaikan bahwa revolusi industri terjadi empat kali, yaitu :

1. Revolusi industri pertama terjadi di Inggris pada tahun 1784 di mana penemuan mesin uap dan mekanisasi mulai menggantikan pekerjaan manusia.

2. Revolusi yang kedua terjadi pada akhir abad ke-19 di mana mesin-mesin produksi yang ditenagai oleh listrik digunakan untuk kegiatan produksi secara masal.

3. Penggunaan teknologi komputer untuk otomasi manufaktur mulai tahun 1970 menjadi tanda revolusi industri ketiga.

4. Saat ini, perkembangan yang pesat dari teknologi sensor, interkoneksi, dan analisis data memunculkan gagasan untuk mengintegrasikan seluruh teknologi tersebut ke dalam berbagai bidang industri. Gagasan inilah yang diprediksi akan menjadi revolusi industri yang berikutnya yaitu Revolusi Industri 4.0. Angka empat pada istilah Industri 4.0 merujuk pada revolusi yang ke empat.

Adapun tahapan revolusi industri 1 sampai 4 dapat dilihat pada Gambar 5 berikut.

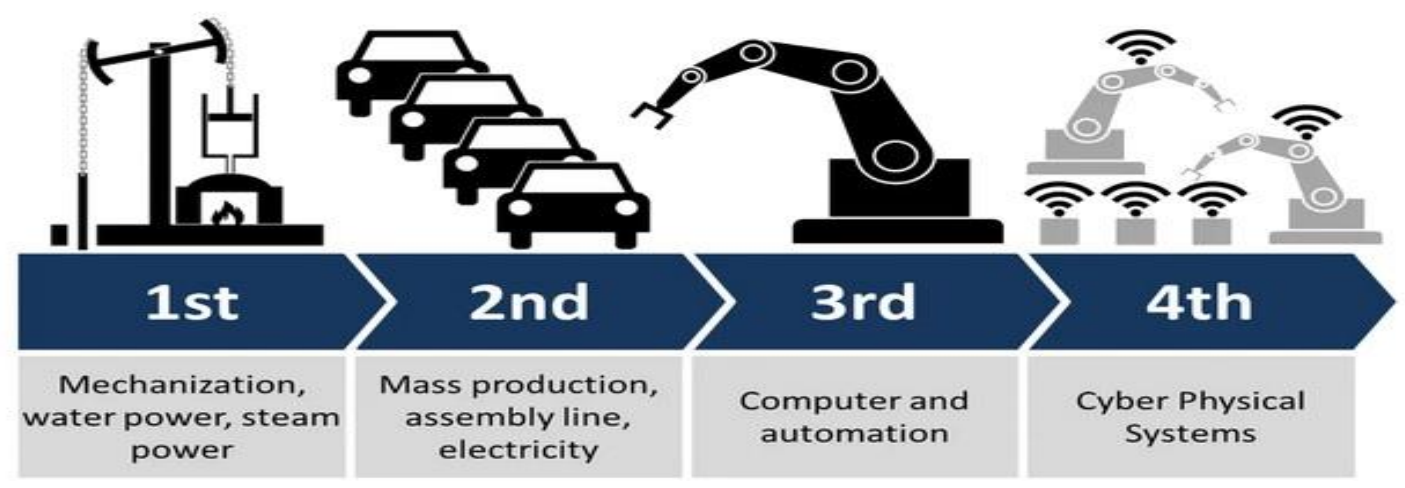

Sumber : http://www.allaboutlean.com/industry-4-0/

Gambar 1

Tahapan Revolusi Industri 
Prof. Klaus Martin Schwab dalam Ghufron (2018), dalam bukunya The Fourth Industrial Revolution (2017) menyebutkan bahwa saat ini kita berada pada awal sebuah revolusi yang secara mendasar mengubah cara hidup, bekerja dan berhubungan satu sama lain. Perubahan itu sangat dramatis dan terjadi pada kecepatan eksponensial. Ini memang perubahan drastis dibanding era revolusi industri sebelumnya. Revolusi digital dan era disrupsi teknologi adalah istilah lain dari industri 4.0. Disebut revolusi digital karena terjadinya proliferasi komputer dan otomatisasi pencatatan di semua bidang. Industri 4.0 dikatakan era disrupsi teknologi karena otomatisasi dan konektivitas di sebuah bidang akan membuat pergerakan dunia industri dan persaingan kerja menjadi tidak linear.

Salah satu karakteristik unik dari industri 4.0 adalah pengaplikasian kecerdasan buatan atau artificial intelligence. Salah satu bentuk pengaplikasian tersebut adalah penggunaan robot untuk menggantikan tenaga manusia sehingga lebih murah, efektif, dan efisien(Tjandrawinata, 2016).

Era IR 4.0 pada prinsipnya adalah memberdayakan peran digitalisasi manufaktur dan jaringan suplai yang melibatkan integrasi informasi dari berbagai sumber dan lokasi. Pemanfaatan informasi digital tersebut digunakan untuk menggerakkan manufaktur dan distribusi fisik. Integrasi antara teknologi informasi dan teknologi operasi ini ditandai dengan koneksi perpindahan lompatan peran fisik ke digital ke fisik seperti yang terlihat pada Gambar 2 berikut.

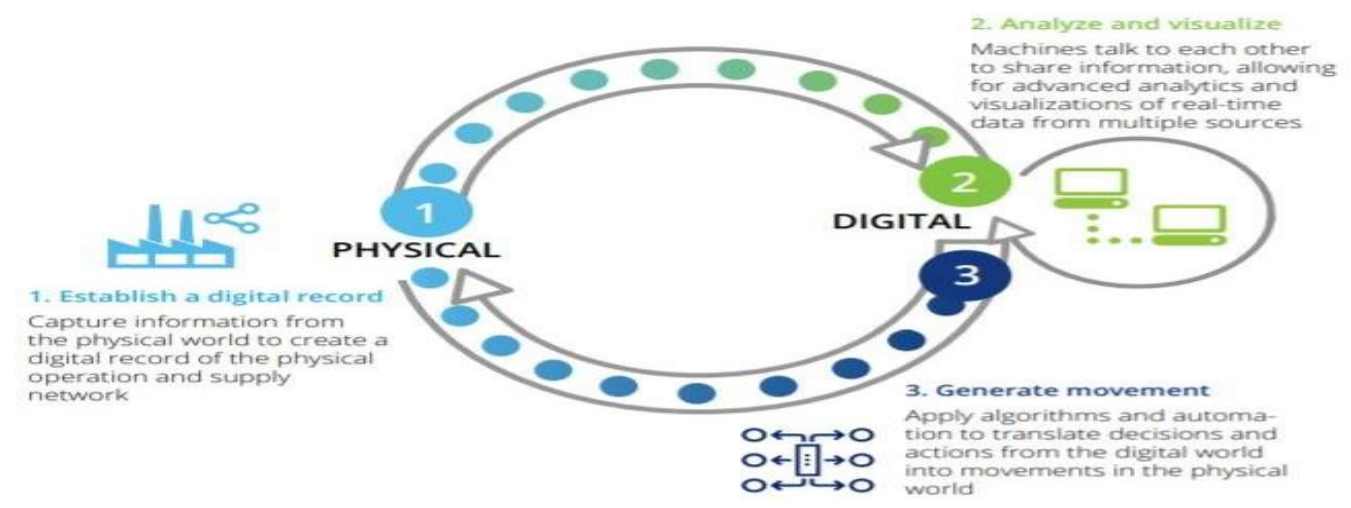

Sumber : www.researchgate.net (2008-2020)

\section{Gambar 2 \\ Lompatan Fisik-Digital-Fisik Pada Industri 4.0}

Zezulka, Marcon, Vesely, \&Sajdl,(2016) menggunakan terminologi Industri 4.0 dalam tiga faktor yang saling terkait, yaitu: (i) digitalisasi dan integrasi teknis sederhana-hubungan ekonomis dengan teknis yang rumit- jaringan ekonomis yang kompleks, (ii) digitalisasi penawaran produk dan layanan, dan (iii) model pasar baru. Semua aktivitas manusia ini saling berhubungan dengan banyak sistem komunikasi saat ini.

Teknologi yang paling banyak digunakan adalah Internet of Things (IoT), Internet of Service (IoS), dan Internet of People (IoP) yang bertumpu pada Sistem-Fisik-Cyber (Cyber-Physical-Systems). Teknologi ini memungkinkan entitas komunikasi (dalam lingkungan Industri 4.0) untuk bertautan satu sama lain dan memanfaatkan data dari produsen selama siklus kehidupan sistem tanpa dibatasi oleh sekat perusahaan dan negara. Semua pihak yang terkait dapat memperoleh informasi dan data yang relevan setiap saat sehingga dapat mengetahui dengan lebih pasti perkembangan yang terjadi dalam pasokan, pengolahan dan pengangkutan sebagai basis perencanaan, pengelolaan dan evaluasi usaha. Pola komunikasi juga mengalami perubahan tidak hanya terbatas antar manusia (Customer to Customer) tapi juga antara manusia dengan mesin (Costumer to Machine) dan antara mesin ke mesin (Machine to Machine) (Cooper dan James 2009).

\section{B. METODE PENELITIAN}

\section{Pendekatan dan Jenis Penelitian}

Jenis penelitian ini adalah literature review (studi literatur). Menurut Danial dan Warsiah (2009), studi literatur adalah merupakan penelitian yang dilakukan oleh peneliti dengan mengumpulkan sejumlah bukubuku, majalah yang berkaitan dengan masalah dan tujuan penelitian. Teknik ini dilakukan dengan tujuan untuk mengungkapkan berbagai teori-teori yang relevan dengan permasalahan yang sedang dihadapi/diteliti sebagai bahan rujukan dalam pembahasan hasil penelitian.Sedangkan menurut Syaodih (2009), adalah rangkaian penelitian yang berkenaan dengan metode pengumpulan datapustaka, atau penelitian yang obyek 
penelitiannya digali melalui beragaminformasi kepustakaan (buku, ensiklopedi, jurnal ilmiah, koran, majalah, dandokumen).

Adapun pendekatan yang dilakukan dalam penelitian ini adalah pendekatan filosofis dan pedagogis. Menurut Katsof (1987) dalam Faiqoh (2013), pendekatan filosofis merupakan pendekatan yang dilakukan untuk melakukan penalaran dan penyusunan suatu data secarasistematis berdasarkan sudut pandang tertentu (dalam hal ini sudut pandang yang digunakan adalah sudut pandang sejarah dalam pembelajaran). Sedangkan pendekatan pedagogis merupakan pendekatan untuk menjelaskan data secara lebih rinci dengan menggunakan teori peletakan genetic moment sejarah dalam pembelajaran.

\section{Sumber Data}

Data yang digunakan dalam penelitian ini adalah data sekunder. Data sekunder adalah sumber data yang tidak langsung memberikan data kepada pengumpul data, misalnya lewat orang lain atau lewat dokumen (Sugiyono, 2015). Data dalam penelitian ini bersumber dari buku, jurnal ilmiah, koran atau majalahonline, tugas akhir baik itu skripsi, tesis, maupun disertasi.

Penelitian ini dilakukan untuk mengetahui manfaat digitalisasi proses logistik dan dampak keberlanjutan digitalisasi dalam logistik dilakukan melalui studi literatur yaitu menemukan berbagai sumber terkait dan membuat kesimpulan sesuai dengan tujuan penelitian. Kriteria publikasi atau sumber yang digunakan adalah kesesuiaan dengan tema penelitian yang sedang dilakukan. Dalam hal ini, untuk pencarian sumber-sumber tersebut penulis menggunakan kata kunci; digitalisasi, logistik, digitalisasi logistik, dan industri 4.0.

Adapun literatur utama yang digunakan dalam penelitian ini adalah penelitian yang dilakukan oleh Suharman \& Hari (2019) yang dipublish dalam Jurnal Manajemen Industri dan Logistik Politeknik APP Jakarta. Penelitian tersebutmengkaji dan mempelajari konsep Industri 4.0 mengenai penerapannya di Indonesia dengan mengangkat lima teknologi utama Industri 4.0, yaitu Artificial Intelligence (AI), Internet of Things (IoT), Wearable Technology (WT), Advanced Robotic (AR) dan 3D Printing (3DP) pada berbagai industri dan manufaktur.Penelitian tersebut dipilih berdasarkan pertimbangan meengenai relevansinya dengan rumusan masalah pada penelitian ini.

Sumber utama lainnya adalah beberapa jurnal antara lain: Tredinnick (2017) dan Mohammadi dan Minaei (2019) yang melakukan penelitian mengenai (AI); Malek et al. (2017) dan Kersten et al. (2019) yang melakukan penelitian dalam bidang Internet of Things(IoT); Ibric,Duric,Parojcic, \& Petrovic (2009) yang melakukan peelitian dalam bidang Advanced Robotik (AR); Schork (2017) yang meneliti teknologi $3 D$ Printing; serta penelitian-penelitian lain yang dianggap relevan untuk menjadi sumber literatur bagi penelitian ini.

Gambar 3 berikut adalah gambaran mengeian alur penelitian yang dilakukandalam penelitian ini.

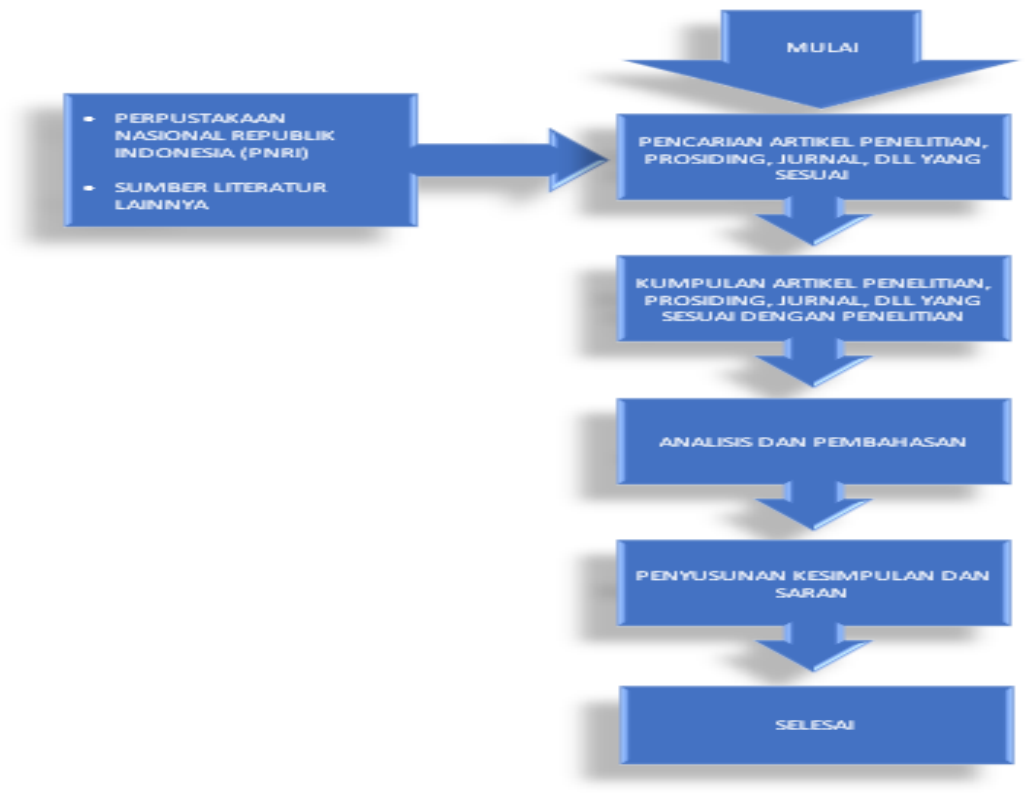

Gambar 3

Alur Metode Penelitian

Erwin Raza et.al (Manfaat Dan Dampak Digitalisasi Logistik Di Era Industri 4.0...) 


\section{HASIL PENELITIAN DAN PEMBAHASAN}

\section{Manfaat Digitalisasi Proses Logistik di Era Industri 4.0}

Dalam era Revolusi Industri 4.0, teknologi informasi telah mengambil peran sangat penting dalam mengubah lanskap industri dan perkembangan bisnis. Terutama, dalam hal cara pelaku bisnis menawarkan produk dan jasanya. Industri logistik diperkirakan akan terus mengalami perkembangan dalam beberapa tahun mendatang, berkat perkembangan $e$-commerce(Iip, 2019).

Industry 4.0 merupakan era yang memberdayakan peran digitalisasi manufaktur dan jaringan suplai yang melibatkan integrasi informasi digital dari berbagai sumber dan lokasi untuk menggerakkan manufaktur dan distribusi secara fisik. Terdapat lima teknologi utama Revolusi Industri 4.0, yaitu Artificial Intelligence (AI), Internet of Things (IoT), Wearable Technology (WT), Advanced Robotic (AR) dan 3D Printing (3DP). Masing-masing komponen teknologi dapat dimanfaatkan pada berbagai industry dan manufaktur. Pemanfaatan Revolusi Industri 4.0 diyakini akan memberikan manfaat dan keuntunganyang lebih banyak (misalnya kinerja menjadi lebih efektif dan lebih efisien)(Suharman dan Hari, 2019).

\section{a. Artificial Intelligence (AI)}

Terdapat banyak definisi mengenai yaitu Artificial Intelligence (AI) atau yang sering kita sebut sebagai kecerdasan buatan. Menurut Russel dan Norvig (2009), Artificial Intelligence (AI) adalah sebuah kondisi dimana sebuah mesin mampu meniru fungsi kognitif yang dikaitkan dengan pikiran manusia. AI dianggap sebagai pendorong utama transformasi digital yang memiliki potensi untuk memperkenalkan sumber pertumbuhan baru. Sedangkan menurut Tredinnick (2017), AI adalah sekelompok teknologi dan pendekatan komputasi yang berfokus pada kemampuan komputer untuk membuat keputusan rasional yang fleksibel dalam menanggapi kondisi lingkungan yang seringkali tidak dapat diprediksi. Pemanfaatan AI telah berhasil diuji di berbagai bidang seperti kendaraan tak berawak yang otonom, diagnosis medis, pengenalan suara, video game, dan lainnya (Mohammadi dan Minaei, 2019).

Meskipun para peneliti tidak memberikan pernyataan yang jelas tentang bagaimana Artificial Intelligence(AI) di bidang manufaktur didefinisikan dibandingkan dengan Machine Learning (ML), mereka sepakat bahwa kedua konsep tersebut berharga untuk Industri 4.0 dan terutama untuk operasi pabrik Cerdas yang menggunakan "perkembangan inovatif baru dalam teknologi digital termasuk robotika canggih dan kecerdasan buatan" (Tjahjono, Esplugues, Ares,\& Pelaez, 2017). Sementara itu, Daehn dan Taub (2018) memperkenalkan konsep "Robotic Blacksmith" untuk menyelidiki cara-cara menggunakan sistem otonom berdasarkan pembelajaran mesin loop tertutup untuk pembentukan logam dalam manufaktur metamorf, yang mencakup semua operasi pembentukan logam.

Mourtzis dan Doukas (2015), menyatakan bahwa dalam rantai pasokan global yang sangat kompleks beberapa keputusan hampir tidak mungkin untuk dihitung dikarenakan jumlah solusi yang banyak bahkan untuk suatu kasus sederhana. Kompleksitas yang begitu tinggi dalam proses pengambilan keputusan, serta kebutuhan akan informasi real-time, membuat teknologi Machine Learning dan AI sangat diperlukan dalam Smart Supply Chain yang adaptif.

\section{b. Internet of Things (IoT)}

Menurut Junaidi (2015), IoT adalah salah satu hasil pemikiran para peneliti yang mengoptimasi beberapa alat seperti media sensor, radio frequency identification (RFID), wireless sensor network serta smart object lain yang memungkinkan manusia mudah berinteraksi dengan semua perlatan yang terhubung dengan jaringan internet. Sedangkan dikutip dari Idcloudhost (2016), Internet of Thing (IoT) adalah sebuah konsep dimana suatu objek yang memiliki kemampuan untuk mentransfer data melalui jaringan tanpa memerlukan interaksi manusia ke manusia atau manusia ke komputer.

Digitalisasi dan transformasi digital terkait telah mempengaruhi hampir semua bidang ekonomi dan industri. Untuk implementasinya diperlukan konsep teknologi baru yang terutama berkaitan dengan manajemen data dan analitik data. Oleh karena itu, diperlukan teknologi yang mampu memproses data dalam jumlah besar. Menurut Malek et al. (2017) teknologi Internet of Thing (IoT) dan Big Data Analysis terbukti menjadi cara yang paling menjanjikan untuk memproses sejumlah besar data secara real-time. Kemampuan untuk mengekstrak data mentah yang sudah diproses dan memvisualisasikannya secara real-time akan membawa perbaikan mendasar di bidang manajemen data. 
AplikasiIoT dan Big DataAnalysis dalam kombinasinya membentuk potensi yang cukup besar untuk berbagai aplikasi di bidang manajemen data. Secara umum IoT mengacu pada visi jaringan objek yang berkelanjutan sehingga objek-objek ini dapat berkomunikasi satu sama lain.Kombinasi aplikasi IoT dan Big DataAnalysisdilakukan dengan arsitektur yang memungkinkan manajemen data end-to-endmulai dari pengambilan data, pemrosesan data, dan visualisasi data(Malek et al., 2017).

Hal tersebut akan menjadi lebih jelas dengan pertimbangan arsitektur IoT seperti yang dicontohkan pada Gambar 4 berikut.

User Domain

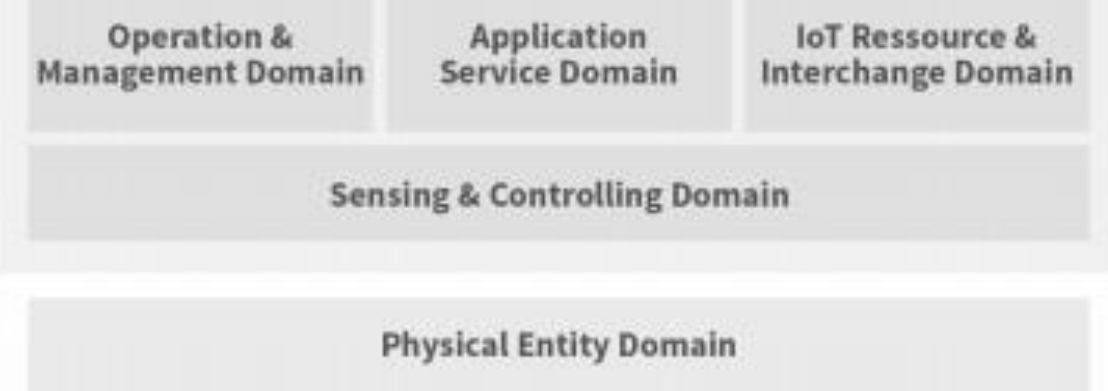

Sumber : Kersten et al. (2019)

\section{Contoh Arsitektur IoT}

Gambar 4 menunjukkan Fungsi Domain Dalam arsitektur IoT, yang dikembangkan untuk definisi Referensi IoT. Level terendah mengacu pada Domain Entitas Fisik, yang menggambarkan aset fisik yang sedang dipertimbangkan. Level selanjutnya mencakup Sensing and Controlling Domain, yang mewakili tingkat akuisisi data. Tingkat pemrosesan data dibagi menjadi tiga domain, Operasi dan Manajemen, Layanan Aplikasi, Sumber Daya IoT, dan Interchange. Level ini berisi fungsi analisis penting untuk pemrosesan data waktu-nyata. Tingkat terakhir menunjukkan domain pengguna, yang memungkinkan visualisasi data. Namun, tampilan yang lebih rinci mengungkapkan bahwa dasar-dasar untuk deskripsi semantik yang tepat dari sistem tidak ada, karena secara khusus diperlukan untuk bidang logistik (Kersten et al.,2019). Sebagai contoh, penerapan teknologi IoTdalam bidang logistik menghasilkan sistem pasokan yang transparan dan terintegrasi.

\section{c. Wearable Technology (WT)}

Wearable Technology merupakan bagian dari IoT. Menurut Wikipedia (2020), Wearable Technology adalah perangkat elektronik pintar (perangkat elektronik dengan pengontrol mikro) yang dipakai dekat dengan dan/atau pada permukaan kulit, tempat mereka mendeteksi, menganalisis, dan mengirimkan informasi (misalnya sinyal tubuh seperti tanda-tanda vital) atau data sekitar dan yang dalam beberapa kasus memungkinkan biofeedback langsung kepada pemakainya.

Robinson (2018), dalam tulisannya mengenai WT dalam supply chain menjelaskan bahwa WTmengacu pada perangkat yang terhubung ke sumber internet dan memungkinkan pekerja untuk melakukan tugas rantai pasokan tanpa perlu mengambil ruang atau sumber daya tambahan. Pada dasarnya, WT adalah tablet jenis baru di pergelangan tangan, wajah, kepala, atau bagian tubuh lainnya.

Di masa lalu, penggunaan WT tidak praktis. Pekerja tidak bisa membawa tablet yang diikat ke dada mereka dan memasukkan data secara manual sambil tetap melakukan pekerjaannya dalam supply chain. Namun kini, WT modern seperti jam tangan Apple, Smart Watch Samsung, Fitbit, dan Google Glasses, memungkinkan pekerja melakukan tugas-tugas penting, dan pada saat yang sama, perangkat yang dapat dikenakan bersama dengan IoT terus menyediakan data untuk ERP organisasijika diintegrasikan ke sistem lain, di dalam cloud melalui perangkat Bluetooth berenergi rendah, Wi-Fi, atau identifikasi frekuensi radio (RFID). 


\section{d. Advanced Robotic (AR)}

Robot dengan logika telah dikembangkan dan digunakan di bidang pengendalian proses yang memungkinkan untuk diekspresikan dalam bentuk linguistik sederhana IF (A) THEN (B) dengan fungsi yang ditetapkan (Suharman \& Hari, 2019). Contoh sederhana adalah pemanas kipas yang diatur oleh 4 aturan. Aturan-aturan ini mempetakan ke empat set Fuzzy COLD, COOL, WARM dan HOT. Jadi, misalnya jika suhu ruangan adalah $18^{\circ} \mathrm{C}$ maka menurut peraturan 2 kecepatan kipas adalah sedang, dengan tingkat kebenaran 0,7 dan oleh peraturan 3 kecepatan kipas rendah dengan tingkat kebenaran 0,3. Proses defuzzification ini memungkinkan dicapainya kecepatan yang tepat dari kecepatan kipas (Ibric, Duric, Parojcic, \& Petrovic., 2009).

Fuzzy logic dari robot yang merepresentasikan temperatur ruang seperti pada Gambar 4.2. berikut.

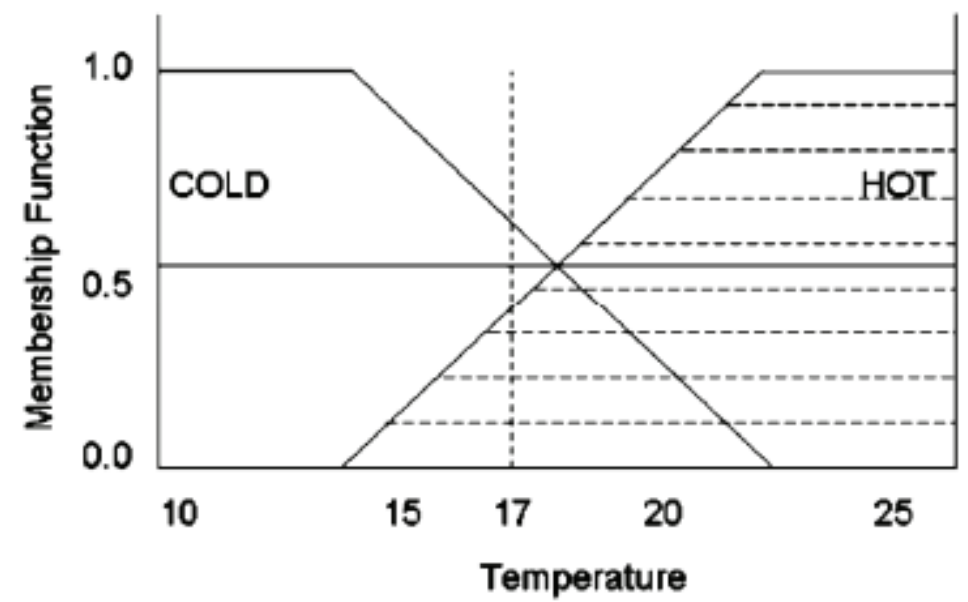

Sumber : Ibric et al. (2009)

\section{Gambar 5}

Fuzzy Logic Untuk Merepresentasikan Temperatur Ruang

Dengan digitalisasi, Industri 4.0 juga mendukung flow informasi yang bersifat real time serta perbaikan dalam rantai suplai dan dalam hal transparansi dan fleksibilitas.

\section{e. 3D Printing (3DP)}

Pencetakan 3D telah digunakan oleh industri otomotif dan dirgantara untuk membangun prototipe untuk beberapa waktu sekarang. Namun, selama beberapa tahun terakhir, teknologi pencetakan 3D telah berkembang dengan pesat. Penelitian yang dilakukan oleh Schork (2017) menghasilkan enam teori tentang bagaimana teknologi ini akan mempengaruhi masyarakat secara keseluruhan dan industri logistik.

Schork mengemukakan 6 teori tentang bagaimana 3D Printing akan mengubah logistik. Berikut penjabarannya :

1. Pencetakan 3D akan menawarkan peluang untuk kustomisasi massal dan produksi terdesentralisasi.

Melihat seberapa cepat berbagai teknologi cetak 3D telah berkembang sejauh ini, dapat mengasumsikan bahwa semakin banyak industri akan berinvestasi dalam 3DP. Banyak barang yang saat ini diproduksi secara massal dengan proses tradisional yang mahal akanberalih diproduksi dalam jumlah besar menggunakan pencetakan 3D dengan biaya yang lebih terjangkau.

2. Pengiriman last-mile akan meningkat

Visi yang diupayakan dengan teknologi 3DP terlihat seperti ini: Barang tidak perlu lagi dikirim di belahan dunia lain, karena barang tersebut dapat dicetak dekat dengan konsumen.

3. Pasar untuk printer desktop 3D akan terus tumbuh

Fakta bahwa teknologi ini pada dasarnya terbuka untuk siapa saja membuat jumlah orang yang ingin menggunakan teknologi ini terus mengalami pertumbuhan pada tahun-tahun mendatang. Generasi yang akan datang diharapkan dapat mencetak bidak catur atau blok bangunan dalam semalam.Desain dapat diunduh dari inetrnet atau dibuat dengan bantuan aplikasi. Objek tiga dimensi disiapkan dalam format file STL yang dapat dibaca oleh Printer 3D mana pun. Cukup kirim file ke printer desktop - di rumah 
atau di toko cetak 3D. Toko cetak 3D pertama di dunia telah dibuka di Zurich pada tahun 2012. Toko cetak tambahan dibuka di Munich dan Wina pada tahun 2014.

4. 3DP akan membuat dunia lebih hijau

Beberapa manfaat 3DP antara lain : (i) Penggunaan komponen yang lebih ringan dan mengurangi konsumsi bahan bakar di industri dirgantara akan mengurangi emisi CO2; (ii) Lebih sedikit konsumsi bahan untuk proses cetak 3D, tidak seperti proses pembuatan tradisional, hanya mengkonsumsi bahan yang dibutuhkan untuk produk akhir; (iii) Kebutuhan untuk pengiriman jarak jauh dihilangkan, sehingga mengurangi emisi; (iv) Tidak perlu lagi menyimpan komponen pengganti secara fisik. Menyimpan cetak biru dalam penyimpanan digital menghemat sumber daya.

5. Suku cadang pengganti akan disimpan sebagai model data di gudang virtual dan dicetak sesuai permintaan

3DP memungkinkan untuk menghemat banyak ruang penyimpanan dikarenakan suku cadang pengganti untuk alat dan mesin dengan fungsionalitas yang ditingkatkan dapat diadaptasi secara digital dan dicetak hanya jika diperlukan. Ini menghemat bahan dan sumber daya.

6. Otoritas bea cukai akan kehilangan peran pengawasan mereka

Prospek peningkatan sirkulasi cetak biru digital secara global dan produk yang dicetak dekat dengan konsumen di tahun-tahun mendatang akan berdampak pada tidak ada lagi penyeberangan perbatasan secara fisik, artinya tidak ada lagi peran bagi otoritas bea cukai.

Revolusi Industry 4.0 dapat diartikan sebagai pergeseran dalam manajemen menuju pendekatan nilai yang semakin terdesentralisasi, self regulating, creation,dan diaktifkan oleh konsep dan teknologi Cyber Physical System, Internet of Thing, cloud, smart factories. Dengan digitalisasi, Industri 4.0 juga mendukung flow informasi yang bersifat real time sertaperbaikan dalam rantai suplai dan dalam hal transparansi dan fleksibilitas.Amiruddin (2019).

Kayikci (2018) menyatakan bahwa penggunaan teknologi digital dan aplikasinya dalam perusahaan Fast Moving Consumer Goods(FMCG) dan penyedia layanan transportasi memiliki dampak keberlanjutan yang sangat besar, terutama sehubungan dengan implikasi ekonomi. Potensi besar digitalisasi dalam logistik dapat terlihat dalam hal biaya logistik, waktu pengiriman, keterlambatan, inventaris, masalah keandalan dan fleksibilitas. Menurut Barczaket al. (2019) implementasi dan penggunaan teknologi digital akan berpengaruh pada peningkatan tingkat inovasi perusahaan.Pada saat yang sama akan menyiratkan perubahan dalam manajemen logistik yang akan membangun atau membuat perusahaan mendapatkan keunggulan kompetitif pada 3 hingga 5 tahun berikutnya.

\section{Dampak Keberlanjutan Digitalisasi Dalam Logistik di Era Industri 4.0}

Evolusi baru dari industri yang disebut Industry 4.0 dan teknologi terkaitnya seperti Internet of Things, big analitic data, dan system cyber-physical memiliki dampak potensial yang belum dapat diketahui dengan pastidampak dankeberlanjutannya.

Bonilla et al. (2018) melakukan penelitian untuk membahas dampak keberlanjutan dan tantangan Industri 4.0.Penelitian merekamempelajari perspektif sebab-akibat pada teknologi Industri 4.0 yang diterapkan untuk kegiatan manufaktur dan dukungan dengan menganalisis efeknya yang secara langsung terkait dengan kelestarian lingkungan. Hasilnya mereka menyimpulkan bahwa konvergensi teknologi Industri 4.0 menuju platform Tujuan Pembangunan Berkelanjutan atau Sustainable Development Goals(SDG) dimungkinkan tetapi membutuhkan inovasi dan kebijakan yang mendukung. Ketika diintegrasikan dengan Tujuan Pembangunan Berkelanjutan, Industry 4.0 diharapkan mendorong peluang untuk respons yang lebih proaktif, tetapi integrasi nyata hanya akan terjadi melalui penggunaan platform inovasi lingkungan yang mapan untuk memastikan kinerja lingkungan berjalan dengan baik. Hasil menunjukan bahwa fungsionalitas yang muncul menawarkan berbagai peluang untuk kelestarian lingkungan ketika direncanakan secara memadai.

Ghobakhloo (2020) melakukan penelitian dengan tujuan untuk mengidentifikasi secara sistematis fungsi keberlanjutan Industri 4.0.Hasilnya menunjukkan bahwa ada hubungan yang kuat di antara berbagai fungsi keberlanjutan Industri 4.0. Berdasarkan hasil analisis Matrice d'Impacts Multiplication Appliquée àun Classement (MICMAC) menunjukan bahwa fungsi keberlanjutan ekonomi seperti efisiensi produksi dan inovasi model bisnis cenderung menjadi hasil yang lebih cepat dari Industri 4.0.

Penelitian yang dilakukanKayikci (2018), menyatakan bahwa digitalisasi diharapkan dapat menciptakan nilai yang jauh lebih besar bagi masyarakat dalam hal ekonomi.Dalam hal ini, bisnis, regulator dan pembuat 
kebijakan perlu berkolaborasi untuk memaksimalkan nilai bagi bisnis dan masyarakat yang lebih luas.Masalah keselamatan dan kesehatan juga dapat ditingkatkan dengan digitalisasi dalam logistik. Ia juga menyatakan bahwa digitalisasi dapat menjadi ancaman potensial terhadap pola tenaga kerja, oleh karena itu penerimaan digitalisasi secara penuh juga menjadi berkurang. Implikasi lingkungan dari digitalisasi paling berdampak pada pengurangan limbah, polusi, dan emisi gas rumah kaca.

Sementara itu, hasil penelitian yang dilakukan Barczaket al. (2019) menunjukkan bahwa penerapan dan penggunaan teknologi digital akan menyiratkan perubahan dalam manajemen logistik, namun dampaknya bagi perusahaan akan beragam, tergantung pada jenis teknologi digital yang diterapkan. Oleh karena itu mereka berasumsi bahwa tidak semua teknologi digital membangkitkan minat yang sama bagi para spesialis logistik, sebab penerapan teknologi digital tersebut akan membawa serta efek berupa risiko yang belum diketahui.Menurut Ritteret al. (2020) jika digitalisasi tidak dimanfaatkansecara tepat dalam model bisnis, kemampuan digitalisasi perusahaan hanyalah akan menjadi pengeluaran tanpa ada pengembalian investasi. Oleh karena itu, penting untuk memetakan di mana dan bagaimana digitalisasi berdampak pada model bisnis yang diberikan.

\section{Dampak Transformasi Digital Dalam Bisnis dan Supply Chain}

Transformasi digital mengubah konteks pasar bagi hampir seluruh bisnis. Perubahan tersebut mengubah berbagai aspek bisnis tidak hanya model operasi binis, tetapi juga bagaimana perusahaan merubah cara-cara dalam menawarkan produk, berinteraksi dengan pelanggan, serta mendapatkan sumber layanan bisnis. Sehingga perusahaan dituntut untuk meredisainsupply chain mereka, dan dengan membangun jaringan supply chain yang lebih terhubung antar seluruh perusahaan yang terlibat. Secara sadar perusahaan dipaksa menggunakan perangkat digital yang saling terhubung memalui situs web yang kompleks.

Dikutip dari Navigating-Infrastructure-and-Assets-in-Digital-Economy (2019), beberapa perubahan penting dalam bisnis yang diakibatkan transformasi digital, antara lain adalah:

\section{a. Perilaku Konsumen}

Konsumen memiliki kekuatan mendorong perubahan dalam fungsi logistik dan supply chain. Penggunaan smartphone dan internet memberikan kemudahan bagi konsumen untuk akses yang sangat luas ke sumber informasi. Perkembangan perdagangan melalui e-commerce, konsumen memiliki beragam pilihan distribusi omni-channel, dan dapat menelusuri setiap channel yang ada, membandingkan berbagai macam produk dan jasa yang ditawarkan, baik dari segi harga, kualitas, dan layanan. Sehingga konsumen dapat membandingkan produk dan jasa yang ditawarkan. Saat ini, konsumen sangat sensitif terhadap harga, kualitas, kenyamanan, fleksibilitas, dan respons layanan yang cepat dari perusahaan. Bahkan konsumen sangat tidak toleran terhadap kualitas produk dan layanan yang buruk, mereka akan segera mengekspos pengalaman yang mereka alami menyangkut produk dan layanan perusahaan, media sosial dan internet. Lebih dari itu, penilaian dan ekspektasi konsumen terhadap produk dan jasa yang ditawarkan, semakin tinggi.

Oleh karena itu, perusahaan harus terus berupaya untuk memperbaiki bisnis mereka, dengan cerdas menggunakan data yang dimiliki untuk mengoptimalkan dan melibatkan pengalaman pelanggan dalam meningkatkan nilai produknya. Sehingga pengalaman pelanggan menjadi bagian integral dari pengembangan produk dan jasa.

\section{b. Inovasi Produk dan rekonfigurasi produk yang sudah ada}

Melalui penjualan e-commerce terdapat ribuan dan bahkan jutaan variasi produk dan jasa yang ditawarkan. Variasi produk yang banyak tersebut menuntut perusahaan terus mengembangkan inovasi untuk menciptakan produk-produk baru atau menduplikasi dengan cepat produk-produk yang laris di pasar. Sebagai akibatnya, siklus hidup produk semakin lebih pendek, risiko cepat usang, mengharuskan perusahaan terus mengembangkan produk baru atau mengkonfigurasi ulang produk lama untuk mempertahankan pangsa pasar.

\section{c. Operasi Bisnis}

Penggunaan teknologi digital, menyebabkan batas-batas organisasi tradisional semakin tidak jelas. Lingkungan pasar semakin kompetitif dan cerdas. Sehingga perusahaan harus menyesuaikan model operasi bisnisnya agar mampu tetap bertahan dan tumbuh dalam ekonomi global yang semakin kompetitif. 
Transformasi digital mendorong perusahaan untuk cepat beradaptasi dengan perubahan tersebut, karena perusahaan hanya memiliki 2 pilihan "mendisrupsi" atau "terdisrupsi (binasa)".

\section{d. Berkembangnya Alih daya (sourcing)}

Teknologi digital mendorong berkembangnya outsourcing (alihdaya), karena memberikan cara baru untuk berkolaborasi dengan perusahaan lain. Terdapat banyak perusahaan melakukan strategi outsourcing dengan mengalihdayakan beberapa kegiatan dan proses ke Perusahaan Penyedia Jasa Logistik (3PL dan 4PL). Tujuannya tak lain adalah untuk memberikan nilai tambah bagi pelanggan, serta mempertahankan profitabilitas perusahaan. Penggunaan teknologi digital, meningkatkan peluang untuk berkolaborasi dengan perusahaan di dalam negeri maupun dengan perusahaan global. Alih daya ini tentunya dapat menciptakan peluang usaha pasar bagi perusahaan Penyedia Jasa Logistik. Beberapa contoh kolaborasi (kemitraan) yang sering dilakukan antara lain dalam bidang: (1) transportasi baik domestik maupun internasional; (2) pergudangan; (3) Freight forwarding; (4) Teknologi dan informasi; (5) Order management dan fulfillment.

\section{Dampak E-Commerce terhadap Logistik}

Perubahan yang pesat dari lanskap e-commerce, memberikan tantangan dan sekaligus peluang baru bagi retailer. Menurut penelitian Forbes, bahwa pasar e-commerce tumbuh menjadi bernilai \$ 6,7 triliun pada tahun 2020. Pemain besar e-commerce dunia seperti Ali Baba, Amazon, Jd.com, Rakuten, e-Bay, dan Walmart terus mengembangkan inovasi untuk menjadi nomor satu dalam ceruk pasar tersebut. Begitu pula pemain e-commerce terbesar di Indonesia seperti Tokopedia, Shopee, Bukalapak, Lazada, BliBli.com, Zalora, dan AliExpres berlomba-lomba memberikan promo menarik serta inovasi yang dapat memanjakan pelanggannya.

Para pemain ini baik pemain e-commerce global maupun domestik telah mendorong pertumbuhan industri e-commerce dan terus bertarung keras satu sama lain untuk meraih keuntungan yang tak ternilai. Perkembangan ini tentunya memberi pengaruh terhadap bisnis jasa logistik.

Beberapa dampak tren e-commerce terhadap bisnis jasa logistik pada tahun, meliputi antara lain:

\section{a. Meningkatnya Pengiriman pada Hari yang Sama (same-day delivery) kepada Konsumen}

Perilaku konsumen terutama millennial yang menuntut pesanan mereka segera sampai pada hari yang sama, menyebabkan meningkatnya persaingan di antara pengecer dalam janji layanan. Milenium ingin agar pesanan mereka dikirimkan dengan cepat; terutama memesan untuk kepuasan yang instan. Produk-produk seperti makanan dan barang mewah (perangkat seluler dan elektronik lainnya) sangat populer dijual untuk pengiriman pada hari yang sama. Di sisi pemasok seperti Amazon dan perusahaan raksasa lainnya bekerja keras untuk menyediakan pengiriman pada hari yang sama (same day-delivery)sambil berupaya menciptakan hemat biaya.

Menurut penelitian Business Insider, nilai pasar pengiriman pada hari yang sama pada akhir tahun lalu (2019) diperkirakan antara \$ 3 dan \$ 4 miliar. Penjualan ini mewakili segmen besar dari pelanggan yang bersedia membayar ekstra untuk pengiriman yang lebih cepat.

\section{b. Adopsi Teknologi dan Otomasi Digital}

Menurut studi 100 tahun Stanford tentang kecerdasan buatan, teknologi Artificial Intelligent (AI) akan mendisrupsi dan mengambil alih pekerjaan layanan logistik. Penggunaan AI dan otomasi terjadi dalam pertukaran antara berbagai titik kontak dalam supply chain. AI dan otomatisasi dapat membantu $e$-commerce dalam melakukan pelacakan dan perekaman data mulai dari proses pemesanan, pengiriman dan pengembalian pada setiap rantai suplai. Sehingga membuat proses ini lebih akurat, cepat, dan mudah.

Beberapa contoh antara lain Platform e-commerce menggunakan data yang dikumpulkan oleh chatbots untuk memahami preferensi pengguna dan melayani mereka dengan lebih baik dan lebih cepat.AI juga digunakan untuk optimalisasi rute, berdasarkan data alamat pengiriman dan jarak yang akan dicakup oleh driver pengiriman. Solusi logistik seluler menggunakan teknologi seperti geo-fencing dan AI untuk membuat pengalaman pengiriman dan pengembalian menjadi mulus dan hemat biaya, untuk pelanggan dan pengecer.Pelopor dalam industri transportasi seperti Mercedes Benz sedang mengerjakan dan menguji angkutan tanpa pengemudi untuk memotong biaya, meningkatkan akurasi dan keamanan, sementara juga meningkatkan pengalaman pelanggan. 
Dompet seluler seperti Google Pay memudahkan pelanggan melakukan pembelian melalui perangkat seluler. Pada tahun 2020, sebagian besar checkout dapat terjadi secara eksklusif melalui perangkat seluler.

\section{c. Supply Chain Management pada Masa Depan}

Dikutip dari McKinsey (2016), digitalisasi supply chain memungkinkan perusahaan untuk memenuhi keinginan pelanggan, mengatasi tantangan di sisi pasokan, dan meningkatkan efisiensisuppy chain. Digitalisasi akan membawa Supply Chain 4.0, menjadi lebih cepat, lebih fleksibel, pengiriman yang lebih kecil, lebih akuran, dan lebih efisien.

Lebih cepat: Layanan dibangun melalui basis big data. Dengan menggunakan big data, maka peramalan (forecast) permintaan dapat dilakukan dengan cepat dan akurat setiap minggu dan bahkan setiap hari. Peramalan dilakukan dengan menggunakan data analitic mulai dari data permintaan, tren pasar, cuaca, liburan hari besar, serta data status mesin untuk suku cadang permintaan.Sehingga dapat memberikan perkiraan permintaan pelanggan yang jauh lebih tepat.

1. Lebih fleksibel: Perencanaan dapat dilakukan secara ad hoc dan real-time, Sehingga memungkinkan respon yang cepat terhadap perubahan permintaan. Proses pengiriman dapat dilakukan secara fleksibel, karena memungkinkan pelanggan untuk menentukan jasa pengriman yang mereka inginkan dan mengalihkan rute pengiriman ke tujuan yang paling nyaman.

2. Lebih kecil: Permintaan pelanggan semakin banyak, produk individual semakin meningkat. Pengiriman akan berubah dari masifikasi (pengiriman barang besar/massif) ke atomisasi (pengiriman barang/paketpaket kecil). Konsep transportasi baru, seperti pengiriman drone untuk paket tunggal dan bernilai tinggi, memungkinkan perusahaan untuk mengelola jarak tempuh secara efisien.

3. Lebih Akurat: Data dan informasi tersedia secara real-time dan transparan mulai dari hulu sampai ke hilir untuk setiap fungsi rantai pasokan. Data dan informasi tersediadari tingkat kinerja layanan keseluruhan, sampai data proses yang sangat terperinci, seperti di mana posisi yang tepat dari truk dalam jaringan. Data pemasok dan penyedia jasa terintegrasi di dalam "supply chain cloud" Sehingga semua pemangku kepentingan dapat mengendalikan dan memutuskan berdasarkan fakta yang sama.

4. Lebih efisien: Efisiensi dalam supply chain didorong oleh otomatisasi dalam tugas fisik dan perencanaan.Contohnya: penggunaan robot dalam pengelolaan gudang, penggunaan truk otonom tanpa awak (driver), optimisasi transportasi lintas perusahaan dengan metode sharing capacity/sharing assets.

\section{KESIMPULAN}

\section{Kesimpulan}

Digitalisasi proses logistik di Era Industri 4.0 yang dicirikan dengan 5 teknologi utama Revolusi Industri 4.0, yaitu Artificial Intelligence (AI), Internet of Things (IoT), Wearable Technology (WT), Advanced Robotic (AR) dan 3D Printing (3DP) memberikan banyak manfaat dalam bidang logistik terutama dalam proses logistik mulai dari raw material hingga penyampaian produk pada konsumen.

Beberapa contoh manfaat dari digitalisasi proses logistik tersebut antara lain adalah teknologi AI yang dapat mewujudkan terciptanya kendaraan tak berawak atau mesin produksi yang bekerja secara otomatis sehingga memudahkan pekerjaan manusia.Pemrosesan data yang besar dan kompleks dapat dimudahkan dengan penggunaan teknologi IoT dan Big Data Analysis. Teknologi IoT juga memungkinkan manusia mudah berinteraksi dengan semua peralatan yang terhubung dengan jaringan internet. Sementara itu, AR atau robot dengan logika telah dikembangkan dan digunakan di bidang pengendalian proses produksi yang memungkinkan untuk diekspresikan dalam bentuk linguistik sederhana dengan aturan IF (A) THEN (B) dengan fungsi yang ditetapkan.

Kemudian, lahirnya teknologi 3DP banyak memberikan manfaat baik itu bagi individu maupun organisasi perusahaan untuk memproduksi barang yang mereka inginkan dan menyampaikannya kepada konsumen. Manfaat tersebut antara lain produksi barang dapat dilakukan dekat dengan konsumen, pengurangan bahan bakar produksi sehingga mengurangi emosi $\mathrm{CO}$, serta penyimpanan cetak biru produk dalam penyimpanan digital dapat menghemat sumber daya. 
Transformasi digital mengubah konteks pasar bagi hampir seluruh bisnis. Beberapa aspek penting yang merubah konteks pasar adalah perilaku konsumen, inovasi produk dan rekonfigurasi produk yang sudah ada, model operasi bisnis, dan berkembangnya alih daya (outsourcing).

Perkembangan perdagangan melalui e-commerce memberi dampak yang signifikan terhadap logistik. Beberapa dampak tren e-commerce terhadap bisnis jasa logistik pada tahun 2020, meliputi antara lain: (1) Meningkatnya pengiriman pada hari yang sama (same-day delivery) kepada konsumen, terutama kaum millennial yang menuntut pesanan mereka segera sampai pada hari yang sama. (2) Adopsi teknologi dan otomasi digital seperti penggunaan teknologi Artificial Intelligent (AI) pekerjaan layanan logistik, seperti penggunaan chatbots dalam layanan pelanggan, optimalisasi rute pengiriman, dan penggunaan teknologi geo-fencing dalam pengiriman, dan penggunaan angkutan tanpa pengemudi.

Digitalisasi pada supply chain memungkinkan perusahaan untuk memenuhi keinginan pelanggan, mengatasi tantangan di sisi pasokan, dan meningkatkan efisiensi supply chain. Digitalisasi akan membawa Supply Chain 4.0, menjadi lebih cepat, lebih fleksibel, pengiriman yang lebih kecil, lebih akuran, dan lebih efisien.

\section{Saran}

Digitalisasi akan terus mempengaruhi dunia bisnis, konten dan arahannya menuntut perhatian yang serius jika tidak ingin ketinggalan. Disarankan bagi parapemangku kepentingan Industri 4.0 antara lain; pemimpin di sektor publik dan swasta, industriawan, dan akademisi, untuk lebih memahami peluang yang ditawarkan oleh revolusi digital. Para pemangku kepentingan diharapkan dapat bekerja bersama untuk memastikan bahwa Industri 4.0 memberikan manfaat terbaik sebagaimana yang diharapkan bersama.

\section{DAFTAR PUSTAKA}

[1]. Ainin, Q. (2017). Pengaruh Model Cooperative Learning Tipe Course Review Horay (CRH) Terhadap Keaktifan Belajar Siswa (Studi kasus pada siswa kelas X IPS 2 SMA Bina Dharma Bandung Tahun Pelajaran 2016/2017).Bandung: Fakultas Keguruandan Ilmu Pendidikan Unpas.

[2]. Ballou, Ronald H. (1992). Business Logistics Management, 4th ed.New Jersey : Prentice-Hall, Inc.

[3]. Barczak, Agnieszka, Izabela Dembińska, \&Lukasz Marzantowicz. (2019). Analysis of the Risk Impact of Implementing Digital Innovations for Logistics Management.MDPI AG. Vol 7, Iss 11, p 815

[4]. Bonilla, Silvia H., Helton R. O. Silva, Marcia Terra da Silva, Rodrigo Franco Gonçalves, \& José B. Sacomano. (2018). Industry 4.0 and Sustainability Implications: A Scenario-Based Analysis of the Impacts and Challenges.Sustainability, 10(10):3740

[5]. Cahn, David. (2019). Chemical Industry Logistics Digitization in a Changing Economy.Adhesives \& Sealants Industry, Vol. 26 Issue 7, p17-19. 3p.

[6]. Chon, Wilam. (2019). Yukki: Digitalisasi Logistik Selalu Diawali dengan Transformasi Digital \& Perubahan Business Process. [online]Available at <https://indoshippinggazette.com/2019/yukkidigitalisasi-logistik-selalu-diawali-dengan-transformasi-digital-perubahan-businessprocess/> [Accessed 10 March 2020]

[7]. Cooper, J., James, A. (2009). Challenges for database management in the Internet of things.IETE Technical Review, 26: 320-329.

[8]. Danial, E, \& Warsiah. (2009). Metode Penulisan Karya Ilmiah. Bandung: Laboraterium Pendidikan Kewarganegaraan.

[9]. Daehn, G.S. and Taub, A., (2018). Metamorphic manufacturing: The third wave in digital manufacturing. Manufacturing Letters. Available at<http://linkinghub.elsevier.com/retrieve/pii/S2213846318300300> [Accessed 5 April 2020]

[10]. Drath, R., \& Horch, A. (2014). Industrie 4.0: Hit or hype?.IEEE industrial electronics magazine, 8(2), pp. 56-58.

[11]. Faiqoh, Zamrotul. (2013). Analisis Peletakan Genetic Moment Sejarah Matematika Dalam Aktifitas Pembelajaran. [online] Available at <http://digilib.uinsby.ac.id/10386/>[Accessed 17 April 2020] 
[12]. Ghufron, MA. (2018, August). Revolusi Industri 4.0: Tantangan, Peluang, dan Solusi Bagi Dunia Pendidikan. Seminar Nasional dan Diskusi Panel Multidisiplin Hasil Penelitian \& Pengabdian kepada Masyarakat, Jakarta.

[13]. Ghobakhloo, Morteza. (2020). Industry 4.0, digitization, and opportunities for sustainability.Journal of Cleaner Production, Vol. 252, 10 April 2020, 119869

[14]. Ibric, S, Z. Duric, J. Parojcic, dan J. Petrovic. (2009). Artificial intelligence in pharmaceutical product formulation: neural computing.Chemical Industry and Chemical Engineering Quarterly, Vol. 15, pp. 227-236, 2009.

[15]. Idcloudhost. (2016). Mari Mengenal Apa itu Internet of Thing (IoT). [online] Available at $<$ https://idcloudhost.com/mari-mengenal-apa-itu-internet-thing-iot/> [Accessed 5 April 2020]

[16]. Kayikci, Yasanur. (2018). Sustainability impact of digitization in logistics. [online] Available at <http://e-resources.perpusnas.go.id:2367/eds/detail/detail?vid=0\&sid=49297483-2ad5-4525-9567291bb1 fd885e\%40sessionmgr4008\&bdata=JnNpdGU9ZWRzLWxpdmU\%3d\#AN=S2351978918302 $245 \& \mathrm{db}=$ edselp $>$ [Accessed 10 March 2020]

[17]. Kothari, C.R. (2004). Research Methodology Methods \& Techniques. New Delhi: New Age International $(\mathrm{P}) \mathrm{Ltd}$.

[18]. Kersten, Wolfgang; Blecker, Thorste; Ringle, Christian M. (2019). Artificial Intelligence and Digital Transformation in Supply Chain Management: Innovative Approaches for Supply Chains. Proceedings of the Hamburg International Conference of Logistics (HICL), No. 27, ISBN 978-37502-4947-9

[19]. Lasa, Hs. (2005). Manajemen Perpustakaan. Yogyakarta : Gama Media.

[20]. Malek, Y.N., Kharbouch, A., El Khoukhi, H., Bakhouya, M., De Florio, V., El ouadghiri, D., Latre, S., Blondia, C. (2017). On the use of IoT and Big Data Technologies for Real-time Monitoring and Data Processing.Procedia Computer Science, 133, pp.429 - 434.

[21]. McKinsey \& Company. (2016). Supply Chain 4.0 - the next-generation digital supply chain. [online] Available at <https://www.mckinsey.com/business-functions/operations/our-insights/supply-chain-40-the-next-generation-digital-supply-chain>[Accessed 5 April 2020]

[22]. Mohammadi, V. \& Minaei, S. (2019). Artificial Intelligence in the Production Process. In: Engineering Tools in the Beverage Industry. [online] Available at<https://linkinghub.elsevier.com/retrieve/pii/B9780128152584000020> [Accessed 5 April 2020]

[23]. Mourtzis, D. and Doukas, M.(2015). On the configuration of supply chains for assemble-to-order products: Case studies from the automotive and the CNC machine building sectors.Robotics and Computer-Integrated Manufacturing, 36, pp.13-24.

[24]. NUS. (2019). Navigating Infrastructure and Assets in Digital Economy. [online] Available at $<$ https://www.tliap.nus.edu.sg/wp-content/uploads/2019/04/Vol18-Feb-TF_Navigating-Infrastructureand-Assets-in-Digital-Economy.pdf $>$ [Accessed 5 April 2020]

[25]. Iip, Otong. (2019). AI, IoT, dan Tantangan Sektor Logistik di Era Revolusi Industri 4.0. [online] Available at <https://ekonomi.kompas.com/read/2019/02/11/114445026/ai-iot-dan-tantangan-sektorlogistik-di-era-revolusi-industri-40?page $=$ all $>$ [Accessed 3 April 2020]

[26]. Junaidi, Apri. (2015). Internet of Things, Sejarah, Teknologi dan Penerapannya : Review. Apri Junaidi Jurnal Ilmiah Teknologi Informasi Terapan, Volume I, No 3

[27]. Prasetyo, Hoedi \& Sutopo, Wahyudi. (2017). Industri 4.0: Telaah Klasifikasi Aspek dan Arah Perkembangan Riset.Jurnal Teknik Industri, Vol. 13, No. 1

[28]. Ritter, Thomas, Carsten Lund Pedersen. (2020). Digitization capability and the digitalization of business models in business-to-business firms: Past, present, and future.Industrial Marketing Management, 86:180-190

[29]. Robinson, Adam. (2018). Wearable Technology in the Supply Chain: 3 Core Benefits. [online] Available at <https://cerasis.com/wearable-technology-in-the-supply-chain/> [Accessed 5 April 2020] 
[30]. Schork, Tatjana. (2017). Six Theories from AEB About How 3D Printing Will Change Logistics. Paper. AEB GmbH.

[31]. Siagian, Yolanda M. (2005). Aplikasi Supply Chain Management Dalam Dunia Bisnis.Jakarta : Gramedian Widiasarana.

[32]. Strandhagen, Jan; Fragapane, Giuseppe ; Sharma, Nakul. (2017). Logistics 4.0 and Emerging Sustainable Business Models.Advances in Manufacturing, Issue 4/2017

[33]. Sugiyono. (2015). Metode Penelitian Kombinasi (Mix Methods). Bandung: Alfabeta.

[34]. Suharman, Hari Wisnu Murti. (2019). Kajian Industri 4.0 Untuk Penerapannya di Indonesia. Jurnal Manajemen Industri dan Logistik, Vol. 03 No. 01. (01-13)

[35]. Sukmana, Ena. (2005). Digitalisasi Pustaka. [online] Available at $<$ https://www.researchgate.net/publication/236965703_DIGITALISASI_PUSTAKA>[Accessed 10 March 2020]

[36]. Supplycahinindonesia. (2019). Digitalisasi Logistik: Masalah Domestik Sangat Besar. [online] Available at <https://supplychainindonesia.com/new/digitalisasi-logistik-masalah-domestik-sangatbesar/>[Accessed 10 Maret 2020]

[37]. Syaodih, Nana. (2009). Metode Penelitian Pendidikan.Bandung : PT. Remaja Rosdakarya.

[38]. Tjahjono, B., Esplugues, C., Ares, E. and Pelaez, G. (2017). What does Industry 4.0 mean to Supply Chain?.Procedia Manufacturing, 13, pp.1175-1182.

[39]. Tredinnick, L..(2017). Artificial intelligence and professional roles.Business Information Review, 34(1), pp.37-41.

[40]. Walters, Donald. (2003). Logistics, an introduction to supply chain management.Milan : Palgrave Mc.

[41]. Zezulka, F., Marcon, P., Vesely, I., Sajdl, O. (2016). Industry 4.0 - An introduction in the phenomenon.IFAC-Papers OnLine, 49-25 (2016) 008-012. 